\title{
The Attitude toward Child Rights Scale: Validity and Reliability Studies ${ }^{\mathrm{i}}$
}

\author{
Selma Yel ${ }^{1}$, Tuğba Dönmez ${ }^{2, *}$ \\ ${ }^{1}$ Gazi Faculty of Education, Gazi University, 06500, Yenimahalle, Ankara, Turkey \\ ${ }^{2}$ Cumhuriyet Primary School, 71700, Delice/Kırıkkale, Turkey
}

Received August 14, 2021; Revised October 12, 2021; Accepted October 27, 2021

\section{Cite This Paper in the following Citation Styles}

(a): [1] Selma Yel, Tuğba Dönmez, "The Attitude toward Child Rights Scale: Validity and Reliability Studies," Sociology and Anthropology, Vol. 9, No. 3, pp. 27 - 36, 2021. DOI: 10.13189/sa.2021.090301.

(b): Selma Yel, Tuğba Dönmez (2021). The Attitude toward Child Rlghts Scale: Validity and Reliability Studies. Sociology and Anthropology, 9(3), 27 - 36. DOI: 10.13189/sa.2021.090301.

Copyright $\bigcirc 2021$ by authors, all rights reserved. Authors agree that this article remains permanently open access under the terms of the Creative Commons Attribution License 4.0 International License

\begin{abstract}
Determining the attitudes of children who have child's rights toward their rights is crucial to revealing their viewpoint on their own rights. The purpose of this study was to develop a valid and reliable attitude scale to determine the attitudes of children toward child's rights. Study group of the study comprised a total of 610 students receiving education in grade three, grade four and grade five in Kırıkkale province. We performed the Exploratory Factor Analysis (EFA) and the Confirmatory Factor Analysis (CFA) on the data. The EFA determined that the scale comprised 19 items and four factors. These dimensions were named "Living", "Development", "Protection" and "Participation". The CFA analysis confirmed the four-factor structure. The Cronbach's Alpha reliability coefficient was $\alpha .80$ for the total scale, $\alpha .82$ for sub-factor one, $\alpha .82$ for sub-factor two, $\alpha .81$ for sub-factor three and $\alpha .89$ for sub-factor four. Also, we calculated item analysis statistics and total item correlations based on the difference of sub-super group averages within the scope of reliability analyses. There was a significant difference between the group with a higher attitude score and the group with a lower attitude score in the scale on the basis of item score and score average. The findings revealed international convention offers the same rights to all children across the world and that the scale can measure the attitudes of children toward their rights in a valid and reliable way.
\end{abstract}

Keywords Children Rights, Scale, Validity,
Reliability

\section{Introduction}

The Convention on the Rights of the Children which has a past of more than 30 years, defends the rights that children possess due to being a child. Although the Convention on the Rights of the Children was recognized in 1989, studies on child's rights date back to the 1970s. There are still debates on whether children should have rights or not or what rights they should have and to what extent. These debates ground on the choice theory. Hart [1] indicates that a person who cannot make a choice about his/her right will not possess the right. According to Hart's choice theory, having a right requires making some kind of choice about that right. Since children -or at least young children- are usually incapable of making a choice, we should question whether they should have a right or not. However, MacCormick [2] suggests that since children clearly have rights, the choice theory is wrong. According to MacCormick [2], rights have a function of protecting the benefits, needs or welfare of individuals. Since children have benefits, they may have rights to protect these rights. One of the principally discussed issues in these two theories is whether the rights protect choices or benefits. From this point of view, it is possible to think that the choice theory focuses on the rights to provide options. In addition the question concerning how to design rights like the right to live which does not require any choice or act, is brought to agenda. According to the benefit theory, children's deprivation of power of choice will not deprive them of fundamental rights. A young child is born with rights and has at least the right to protect Brighouse [3] and Brennan [4] similarly support 
the theory of interest, but that adults choose their rights; states that the rights of children should be protected by their interests. Both theories focus on fundamental rights and the debates over authoritativeness concerning these rights and tasks. Another dimension of the debates is that giving rights to children may weaken the family. In this case a "parent-centered" approach has come to the forefront to solve these debates. Determination of a parenting status is only compatible with children's benefits as long as parenting roles are indeed fulfilled in such a way to protect and develop children's welfare. At this point, there are situations like what rights children will take advantage of, whether parents will have consent or whether they will make children experience something against their will or not. In this case the possible parent-controlled problems to be experienced have directed us toward a "child-centered" approach [5]. Although the debates continue to this day, child's rights are mainly grounded on the Convention on the Rights of the Children. Basic principle of this convention is to protect high benefit of the child. Besides protecting high benefit of the child, item 42 in the convention comprehensively discusses the enhancement of the knowledge and skills of children concerning child's rights, which have right. Additionally, in order to create a world respectful to child's rights, there is a need for studies that will not only teach child's rights but will also enhance positive attitudes of children toward their own rights. As these studies increase, we believe that children will be more skilful at displaying behaviors to take advantage of their rights. However, examining the relevant literature we have encountered no study measuring the attitudes of children toward child's rights. There is a need for studies that will reflect the viewpoint of children on their own rights. This study sought to develop a scale to reveal the attitudes of children toward child's rights. Measuring the attitudes of children toward their own rights will develop a multi-directional viewpoint concerning child's rights.

\section{Method}

This section gave information about the study method, study group, data collection process and tools and the methods used in analysis of the data.

\subsection{Research Model}

The study was a scaling-based study prepared to determine validity and reliability of the Attitude toward child's Rights Scale.

\subsection{Study Group}

Study group of the study comprised grade three, grade four and grade five students receiving education at public and private schools in Kirikkale province. We chose the study group via the convenience sampling method. This method is a sampling method which is performed on people who are accessible and are present in the immediate vicinity and volunteer to take part in the study [6]. In the scale development process we worked with 384 students to conduct the Exploratory Factor Analysis (EFA) and with 226 students to conduct the Confirmatory Factor Analysis (CFA), comprising individual student groups.

\subsection{Development Process of the Scale}

When preparing the scale, we followed the phases specified in the literature. The phases comprised creating an item pool and writing the scale items in such a way to measure the attitudes, receiving expert opinion, performing a pretesting and conducting validity and reliability studies [7],[8].

\subsubsection{Creation of the Item Pool}

In the scale development process, primarily examined the Convention on the Rights of the Children and the attitude toward child's rights scales prepared previously. We conducted interviews with elementary school grade four students receiving education at a public school in the 2019-2020 school year, in an attempt to reach students with similar characteristics to the group whose attitudes would be measured. During the interviews, we asked the students "What do child's rights mean to you?" to determine their emotions, thoughts and behaviors concerning child's rights. Their answers formed a basis for creating the item pool. When writing the attitude items toward child's rights, we chose statements from the answers of the students including the rights mentioned in the Convention on the Rights of the Children. The first item in the CRC is the Preface section and item 5 comprises all four rights of Living, Development, Protection and Participation. Since item 42 and 54 refer to the committee to be established by state parties and the rules they will obey, we excluded these items. Table 1 demonstrates the items written in accordance with the convention. 
Table 1. Items in the Convention on the Rights of the Children and writing of attitude items in accordance with these 1 tems*

\begin{tabular}{|c|c|c|c|}
\hline \multirow{4}{*}{$\begin{array}{l}\text { The Attitude Toward } \\
\text { Child's Rights Scale }\end{array}$} & Themes in CRC & CRC Articles Suitable for Themes & Items No \\
\cline { 2 - 4 } & Right to life & $6 ., 7 ., 8 ., 24 ., 25 ., 26 ., 27 ., 30$. Items & 5., 6., 9., 11. \\
\cline { 2 - 4 } & Right to development & 17., 28., 29., 31. Items & $1 ., 2 ., 3 ., 4$. \\
\cline { 2 - 4 } & Right to protection & $\begin{array}{c}9 ., 10 ., 11 ., 16,32 ., 33 ., 34 ., 35 ., 36 ., 37 ., \\
38 ., 39 ., 40 ., 41 . \text { Items }\end{array}$ & $8 ., 10 ., 15 ., 16 ., 18 ., 19$. \\
\cline { 2 - 4 } & Right to participation & $12,13 ., 14,15$. items & $7 ., 12 ., 13 ., 14 ., 17$. \\
\hline
\end{tabular}

* We rearranged this table after the Exploratory Factor Analysis (EFA) and the Confirmatory Factor Analysis (CFA) and did not include the items excluded from the scale.

We created an item pool of 48 items by gathering the data acquired from the interviews and from the literature. We paid a particular attention to the attitude items written to include intellectual, affective and behavioral elements concerning child's rights.

\subsubsection{Determination of Content Validity and Preparation of the Draft Scale}

We received expert opinion to determine content validity of the statements in the item pool. Content validity is the degree of questions or items in an assessment tool to represent the subjects that a scale aims to measure in a balanced way. It may be deceptive for the person who developed the assessment tool to determine content validity alone. Content validity requires collaboration with domain experts and is determined consulting the experts [8]. Accordingly, we received opinion from eight experts to determine whether the items in the assessment tool measured the attitudes of children toward child's rights or not.

The "Expert Assessment Form" aimed to enable experts to assess the items in the draft form. We asked the experts to express an appropriate opinion for one of the options of "Appropriate", "Should Be Corrected" and "Should Be Removed" for each item in the assessment form. We excluded nine items in which the experts arrived at a consensus and revised seven items.

\subsubsection{Pre-application of the Scale}

In order to test the comprehensibility of the scale, we conducted pretesting studies. We asked 13 elementary school grade four students to answer the draft form. At the end of the application, it took nearly 40 minutes to complete 39 attitude items and the students were not able to comprehend item 11, 19 and 23 . We renewed these items and made them appropriate for the level of the students. We excluded item 28 which was not comprehended by all students from the scale.

\subsubsection{Determination of Construct Validity and Calculation of Reliability}

We submitted the draft form of 38 items to the students receiving education in Kırıkklale to answer online via Google Forms. In order to conduct the exploratory factor analyses of the scale, 384 students answered 38 items. It took nearly 35-40 minutes to complete the total scale. It took nearly one month (30 days) to collect all the scale data. In order to conduct the confirmatory factor analysis, 226 students to whom the scale had not been applied previously, answered the scale of 19 items. It took nearly 15-20 minutes to complete the total scale and nearly 15 days to collect all the data. Then we started the reliability studies and conducted the internal consistency coefficient and statistics studies.

\subsection{Data Collection Tool}

We used the "Attitude toward Child's Rights Scale" as data collection tool. The students accessed the scale via Google Forms. We graded negative items in the three point likert scale reversely.

\subsection{Data Analysis}

We used the SPSS 25 and Amos 22 programs in analysis of the data. Descriptive statistics techniques (mode, median, arithmetic mean, standard deviation, minimum and maximum values) were used to determine the general distribution of their responses to the scale developed for children and to investigate whether the quantitative data showed a normal distribution. The central tendency (mean, mode and median) and central distribution (standard deviation, variance, skewness and kurtosis) values of the scale scores are reported. In addition, the scores obtained from the scale were processed as lower, middle and upper $27 \%$ slices. In addition, frequency and percentage distributions were used in the analysis of the data. The Amos 22 program was used to verify the structures that emerged with the SPSS 25 program.

\section{Findings}

This section included the validity and reliability studies of the Attitude toward Child's Rights Scale.

\subsection{Validity}

\subsubsection{Construct Validity}

It is crucial to determine the construct validity of a scale to show that the assessment tool functions in line with the 
measurement goal. Construct validity of a scale facilitates explaining the results and what the results are related to [8]. We applied the draft scale to 384 students and calculated the Kaiser-Meyer-Olkin (KMO) test to determine the efficiency of the data acquired from the sample via the SPSS 25 statistics program and the Bartlett's test results to test the normal distribution of the data. Table 2 demonstrates the test results concerning whether to perform a factor analysis for the scale or not.

Table 2. Results of the Kaiser-Meyer-Olkin (KMO) sample measurement and the Bartlett's Sphericity

\begin{tabular}{|c|c|c|}
\hline Kaiser Meyer Olkin (KMO) & $\cdot$ & .849 \\
\hline \multirow{3}{*}{ Barlett Sphericity Test } & $\mathrm{X}^{2}$ & 1,896 \\
\cline { 2 - 3 } & $\mathrm{df}$ & 171 \\
\cline { 2 - 3 } & Sig.(p) & .000 \\
\hline
\end{tabular}

Test of The Attitude Toward Child's Rights Scale

In Table 2, according to the results of the Bartlett's Sphericity Test which were the prerequisites for the factor analysis, there was an adequate correlation between the variables $(\mathrm{p}<0.05, \mathrm{p}=0.000)$. According to Table 2 , the $\mathrm{KMO}$ value was 0.849 . Kaiser indicates that as the value found approaches one, it is excellent and if it is below 0.50 , it is unacceptable (excellent at around 0.90, very good at around 0.80 , moderate at around 0.70 to 0.60 and bad at around 0.50) [7]. In addition, the values acquired as a result of the Bartlett's Test were significant $\left(X^{2} ; 1.896\right.$, df; 171, p: .000). Based on these values we agreed that the data was normally distributed and appropriate for a factor analysis. We conducted analyses.

\subsubsection{Exploratory Factor Analysis (EFA)}

We used the Exploratory Factor Analysis (EFA) to obtain information about the nature of factors measured via measurement and to create evidences on construct validity of the scale. We chose the principal component analysis in factor analysis and used "varimax" which is among inclined rotation technics as a rotation method. As a result of the first analysis regarding the data, we found that the scale had six factors and the total factor variance was $52.384 \%$. However, we repeated the analysis procedures at every turn by excluding the items, starting from the lowest, whose item factor load was .40 and below, did not gather in any factor and offered load to multiple factors one by one. We continued the data analyses with the remaining items.

Factor determination is usually based on factor eigenvalues, scree plot diagram and explained variance values of factors [9]. The scree plot diagram in Figure 1 demonstrates eigenvalues of the scale items.

Examining the scree plot diagram in Figure 1, we see that breaking points indicate four factors. In addition, Table 3 demonstrates the EFA values of the scale.

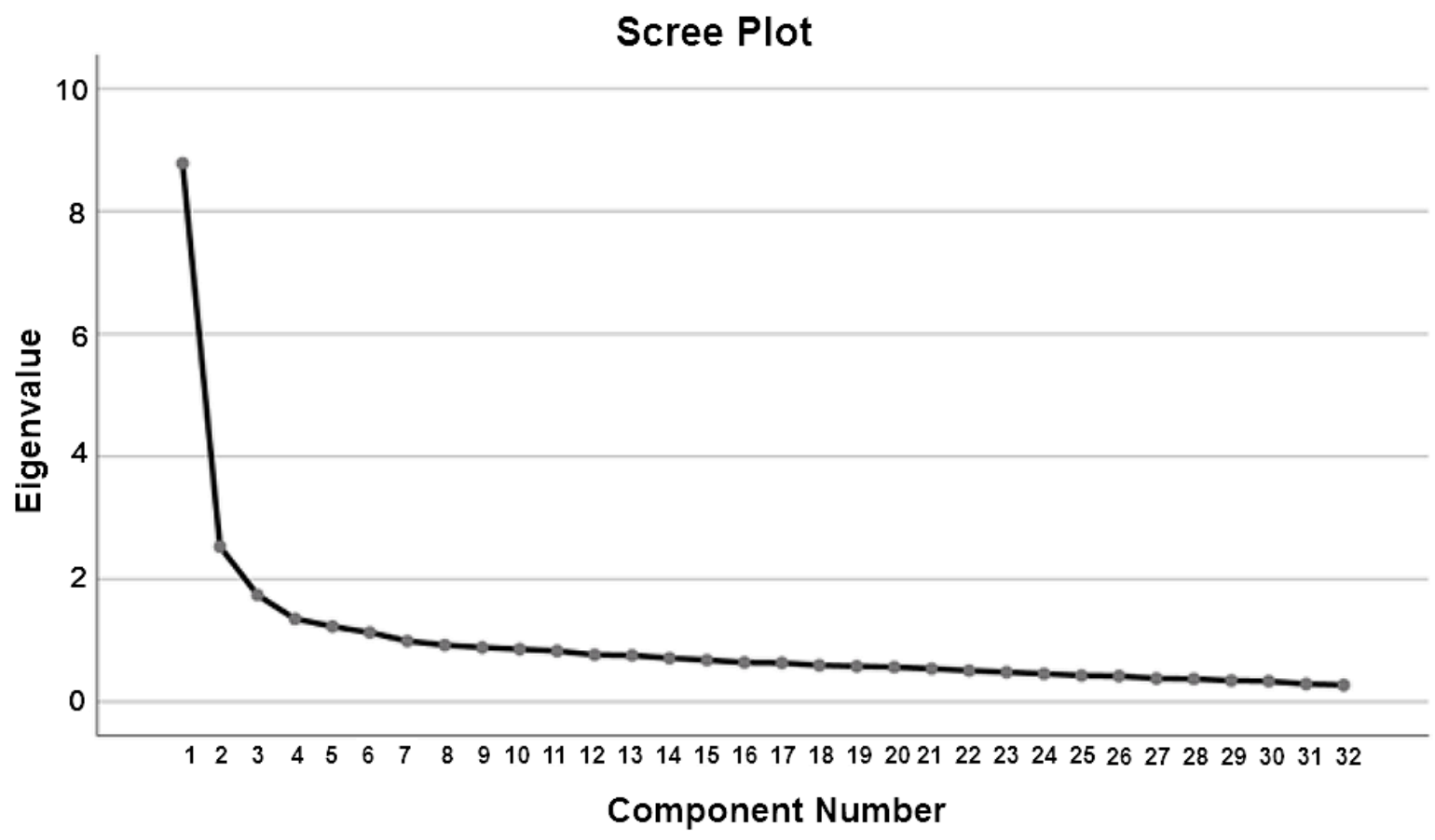

Figure 1. Eigenvalues of the Attitude toward Child's Rights Scale items 
Table 3. The EFA values related to the factors of The Attitude toward Child's Rights Scale items

\begin{tabular}{|c|c|c|c|c|}
\hline Items & \multicolumn{3}{|r|}{3} & 4 \\
\hline 18) Only the children of wealthy families should utilize healthcare services. & .750 & & & \\
\hline 21) When I play with my friends, we should always play the games I want. & .718 & & & \\
\hline 33) I don't like to play with handicapped students at school. & .713 & & & \\
\hline 31) Those younger than 18 years don't need to have an ID card. & .704 & & & \\
\hline 30) I think I should have safe playgrounds at school. & .605 & & & \\
\hline 38) Mischievous students shouldn't have any right in the class. & .538 & & & \\
\hline 32) I'm not shy about telling what social activity I would like to participate at school. & & .749 & & \\
\hline 28) I'm not shy about expressing my thoughts by writing, drawing or telling however I wish to. & & .678 & & \\
\hline 27) I do my best to protect the rights of my friends who are subjected to injustice. & & .613 & & \\
\hline 29) When I'm not able to take advantage of my rights as a child, I ask for help from my elders. & & .572 & & \\
\hline 14) I do not hesitate to ask questions about the subjects I am curious about in class. & & .541 & & \\
\hline 12) Not all children in our class should have the same rights. & & & .847 & \\
\hline 19) No matter what physical properties they have, I think all children have the same rights. & & & .760 & \\
\hline 13) I think I need to protect from all kinds of violence. & & & .566 & \\
\hline 22) I think handicapped children have a right to go to school with others. & & & .517 & \\
\hline 5) I volunteer to take part in projects and studies on child's rights. & & & & .762 \\
\hline 7) When learning child's rights, I don't like to take part in activities we perform in the class. & & & & .642 \\
\hline 6) I try to watch broadcasts on child's rights on radio and television. & & & & .626 \\
\hline 10) I take part in intraclass discussions on child's rights. & & & & .613 \\
\hline \begin{tabular}{|c|} 
\\
Factors \\
\end{tabular} & Eigen & lues & Explain & variance \\
\hline $\mathrm{F} 1$ & 3, & & & 868 \\
\hline $\mathrm{F} 2$ & 2, & & & 066 \\
\hline F3 & 2,2 & & & 736 \\
\hline $\mathrm{F} 4$ & 2,0 & & & 545 \\
\hline Total & 9,7 & & & 315 \\
\hline
\end{tabular}

In Table 3, as a result of the factor analysis the 19-item Attitude toward Child's Rights Scale gathered under four factors and these four factors explained $51.315 \%$ of the total variance. According to factor loads, since loads in the factors where items gather should have at least $10 \%$ distance to each other, we excluded the items which did not abide by this rule and whose factor loads were below 0.40 from the scale as a result of the factor analysis. The items excluded from the scale are as follows.

- I think I have specific rights due to being a child.

- Elders don't need to protect the rights of the children.

- I'm aware that there are children in the world who are not able to take advantage of their rights.

- Children don't need to be taught what rights they have.

- 8) Posts about child's rights on social media attract my attention.

- 9) I read storybooks about child's rights willingly.

- 11) Schools should be places teaching the children their rights.

- 15) I ask my teacher to do activities on child's rights.

- 16) I volunteer to take part in decisions made in the class.

- 17) I volunteer to take part in decisions made at home.

- 20) I think my friends in our class have the same rights as me.

- 23) I think I have the right to be respected at school.

- 24) Girls don't need to have the same rights as boys.

- 25) When I'm not able to solve my problems, I ask for help from my elders.

- 26) When I am subjected to injustice, I make an effort to protect my rights.

- 34) I think playing is my right as a child.

- 35) I think our teacher should choose the class president.

- 36) I would like to take part in studies on child's rights.

37) All children should take advantage of the right to a healthy life equally.

Examining the item numbers in the factors, it can be conclude that there were six items in factor one, five items in factor two, four items in factor three and four items in factor four. Factor one was named "Living", factor two "Participation", factor three "Protection" and factor four "Development".

\subsubsection{Confirmatory Factor Analysis (CFA)}

In order to confirm the structure formed as a result of EFA, confirmatory factor analysis (CFA) was performed with the AMOS 22 program. The DFA path Diagram is shown in Figure 2. 


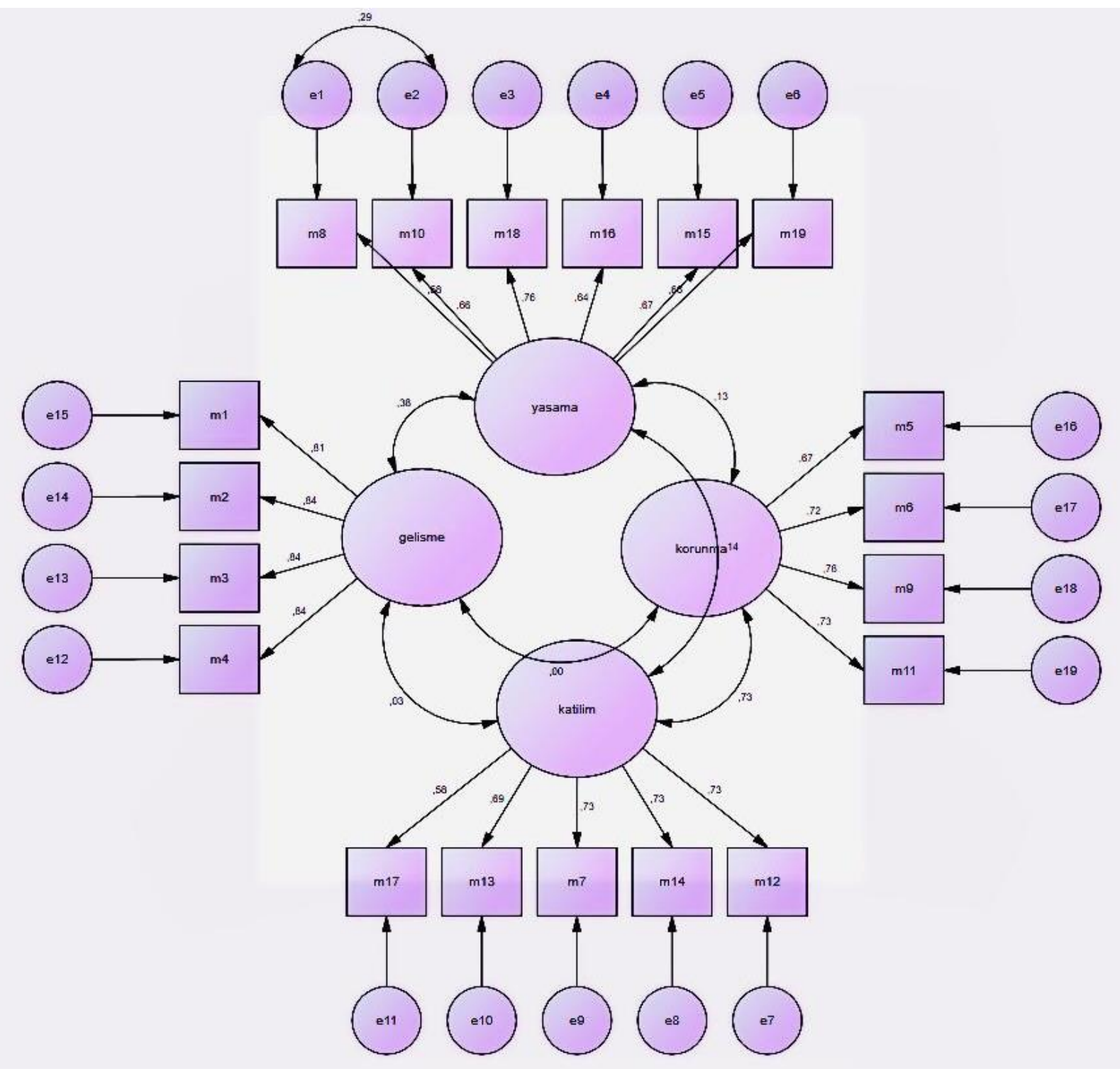

Figure 2. CFA Path diagram 
Table 4. Fit index statistics for the Attitude toward Child's Rights Scale

\begin{tabular}{|c|c|c|c|c|}
\hline Fit Index & Good Fit & Acceptable Fit & Suggested New Model & Evaluation \\
\hline $\mathrm{X}^{2}$ & $0 \leq \chi 2 \leq 2 \mathrm{sd}$ & $2 \mathrm{sd}<\chi 2 \leq 3 \mathrm{sd}$ & $\begin{array}{c}299,704 \\
(\mathrm{sd}: 145)\end{array}$ & Acceptable Fit \\
\hline $\mathrm{p}$ değeri & $.05 \leq \mathrm{p} \leq 1.00$ & $.01 \leq \mathrm{p} \leq .05$ & 0.000 & Good Fit \\
\hline $\mathrm{x}^{2} / \mathrm{df}(\mathrm{sd})$ & $0 \leq \chi 2 / \mathrm{df} \leq 2$ & $2 \leq \chi 2 / \mathrm{df} \leq 5$ & 2,067 & Acceptable Fİt \\
\hline $\mathrm{NFI}$ & $.95 \leq \mathrm{NFI} \leq 1.00$ & $.90 \leq \mathrm{NFI} \leq .95$ & 0.855 & Acceptable Fit \\
\hline TLI & $.95 \leq \mathrm{TLI} \leq 1.00$ & $.90 \leq \mathrm{TLI} \leq .95$ & 0.904 & Acceptable Fit \\
\hline CFI & $.95 \leq \mathrm{CFI} \leq 1.00$ & $.90 \leq \mathrm{CFI} \leq .97$ & 0.918 & Acceptable Fit \\
\hline RMR & $0<\mathrm{SRMR} \leq .5$ & $.5<\mathrm{SRMR} \leq .8$ & 0.058 & Good Fit \\
\hline RMSEA & $0 \leq \mathrm{RMSEA} \leq .05$ & $.05 \leq \mathrm{RMSEA} \leq .08$ & 0.069 & Acceptable Fit \\
\hline
\end{tabular}

The standardized regression coefficients and error variances obtained when the correlations between the e1 and e2 error covariations (item 8 and item 10) collected under the same factor (item 8 and item 10) were allowed by the second level Confirmatory Factor Analysis to increase the fit of the scale are as seen in Figure 2.

It is seen that the standardized regression coefficients of the 19 items in the scale vary between 0.58 and 0.84 . The fact that the standard regression coefficients (factor load) for each item is above 0.32 indicates that the model-data fit is at an acceptable level [9]. In CFA, in order to decide whether the proposed model is compatible with the data set, given in Table $11 ; \chi 2 / s d$ (chi-square/degree of freedom), root mean square error of approximation (RMSEA), root mean square error (RMR), normed fit index (NFI), Turker-Lews index (TLI), and comparative fit index (CFI) values are taken into account and evaluated [10].

When Table 4 is examined, the goodness-of-fit indices are obtained as a result of the 226-person data set and the second level CFA for the 19-item 4-factor measurement tool $[\chi 2 / \mathrm{sd}=2.067 \mathrm{p}<.01 ; \mathrm{NFI}=.85 ;$ TLI: .90; CFI=.91; SRMR=.05; RMSEA = .07]. While evaluating the model in confirmatory factor analysis, chi-square statistical values and fit indices are generally taken into account [11]. According to the reference ranges given in Table 11, the ratio of chi-square $(\chi 2=299.704)$, degrees of freedom $(\mathrm{df}=145) \quad(\chi 2 / \mathrm{df}=2.067)$, NFI $(.855)$, TLI $(.904)$, CFI (.918), RMSEA (.069) has acceptable fit indices and RMR (.058) has good fit indices. Based on these results, it was decided that the proposed 19-item and 4-factor structure was confirmed according to the chi-square value and the fit indices.

\subsection{Reliability}

In order to determine the reliability level in a likert-type attitude scale, it is appropriate to use the $\alpha$ coefficient, which is a criterion of internal consistency developed by
Cronbach. Highness of the $\alpha$ coefficient of the scale indicates that items in the scale are consistent with each other and measure the elements of the same property [7]. From this point of view, we calculated the Cronbach's Alpha coefficient which is the internal consistency coefficient, to determine the reliability of the scale. The Cronbach's Alpha internal consistency coefficient of the Attitude toward Child's Rights Scale was .802. The Cronbach's Alpha reliability coefficient value is accepted to be maximumly reliable above .90 , highly reliable between .90 and .80 and reliable between .79 and .70 [10]. In this case, it is possible to state that the scale is highly reliable. Also, Table 4 demonstrates the Cronbach's Alpha coefficient related to each sub-factor of the scale.

Table 5. The Cronbach's Alpha (CRA) internal consistency coefficients related to the sub-factors of the scale

\begin{tabular}{|c|c|}
\hline Factors & Cronbach-Alfa (Cro) \\
\hline F1 & 0.826 \\
\hline F2 & 0.821 \\
\hline F3 & 0.814 \\
\hline F4 & 0.897 \\
\hline Total & 0.802 \\
\hline
\end{tabular}

Examining Table 5, it can be concluded that the internal consistency coefficients of each factor were reliable. Also we calculated item analysis statistics and total item correlations based on the difference of sub-super group averages within the scope of reliability analyses. In this analysis, the answer sheets are arranged from the highest to the lowest according to total score. $27 \%$ of the answer sheets are separated in a way to create the "super group" from the end of high scores and $27 \%$ are separated in a way to create the "sub group" from the end of low scores. For each item, averages of the two groups are found and the independent samples t-test is conducted for significance of the difference between averages of the two groups [7]. Table 5 demonstrates the results of the t-test. 
Table 6. The t-test results of the item score averages of The Attitudes of the Participants toward Child's Rights according to sub-super groups

\begin{tabular}{|c|c|c|c|c|c|c|c|c|}
\hline & & & $\mathrm{N}$ & Ort. & $S$ & $\mathrm{Sd}$ & $\mathrm{T}$ & $\mathrm{P}$ \\
\hline \multirow{12}{*}{ 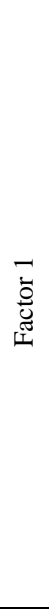 } & \multirow{2}{*}{ Item 18} & $\% 27$ Sub Group & 103 & 3.94 & 1.16 & 204 & -8.329 & .000 \\
\hline & & $\% 27$ Super Group & 103 & 4.95 & 0.41 & & & \\
\hline & \multirow{2}{*}{ Item 21} & $\% 27$ Sub Group & 103 & 3.74 & 1.11 & 204 & -8.412 & .000 \\
\hline & & $\% 27$ Super Group & 103 & 4.79 & 0.60 & & & \\
\hline & \multirow{2}{*}{ Item 33} & $\% 27$ Sub Group & 103 & 3.81 & 1.13 & 204 & -10.231 & .000 \\
\hline & & $\% 27$ Super Group & 103 & 4.96 & 0.19 & & & \\
\hline & \multirow{2}{*}{ Item 31} & $\% 27$ Sub Group & 103 & 3.80 & 1.10 & 204 & -9.968 & .000 \\
\hline & & $\% 27$ Super Group & 103 & 4.92 & 0.33 & & & \\
\hline & \multirow{2}{*}{ Item 30} & $\% 27$ Sub Group & 103 & 3.43 & 1.13 & 204 & -8.708 & .000 \\
\hline & & $\% 27$ Super Group & 103 & 4.67 & 0.91 & & & \\
\hline & \multirow{2}{*}{ Item 38} & $\% 27$ Sub Group & 103 & 3.33 & 1.32 & 204 & -9.494 & .000 \\
\hline & & $\% 27$ Super Group & 103 & 4.70 & 0.62 & & & \\
\hline \multirow{10}{*}{$\begin{array}{l}\text { N } \\
\overline{0} \\
\frac{0}{0} \\
\text { II }\end{array}$} & \multirow{2}{*}{ Item 32} & $\% 27$ Sub Group & 103 & 3.65 & 0.76 & 204 & -11.926 & .000 \\
\hline & & $\% 27$ Super Group & 103 & 4.74 & 0.52 & & & \\
\hline & \multirow{2}{*}{ Item 28} & $\% 27$ Sub Group & 103 & 3.72 & 0.72 & 204 & -11.211 & .000 \\
\hline & & $\% 27$ Super Group & 103 & 4.73 & 0.56 & & & \\
\hline & \multirow{2}{*}{ Item 14} & $\% 27$ Sub Group & 103 & 3.73 & 1.00 & 204 & -10.164 & .000 \\
\hline & & $\% 27$ Super Group & 103 & 4.84 & 0.47 & & & \\
\hline & \multirow{2}{*}{ Item 29} & $\% 27$ Sub Group & 103 & 3.74 & 0.83 & 204 & -11.33 & .000 \\
\hline & & $\% 27$ Super Group & 103 & 4.83 & 0.51 & & & \\
\hline & \multirow{2}{*}{ Item 27} & $\% 27$ Sub Group & 103 & 3.83 & 0.71 & 204 & -10.297 & .000 \\
\hline & & $\% 27$ Super Group & 103 & 4.75 & 0.57 & & & \\
\hline \multirow{10}{*}{ 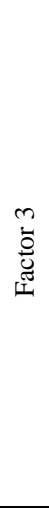 } & \multirow{2}{*}{ Item 12} & $\% 27$ Sub Group & 103 & 3.64 & 1.04 & 204 & -12.276 & .000 \\
\hline & & $\% 27$ Super Group & 103 & 4.93 & 0.25 & & & \\
\hline & \multirow{2}{*}{ Item 19} & $\% 27$ Sub Group & 103 & 3.70 & 1.05 & 204 & -12.323 & .000 \\
\hline & & $\% 27$ Super Group & 103 & 4.98 & 0.14 & & & \\
\hline & \multirow{2}{*}{ Item 13} & $\% 27$ Sub Group & 103 & 4.12 & 0.87 & 204 & -10.168 & .000 \\
\hline & & $\% 27$ Super Group & 103 & 4.99 & 0.10 & & & \\
\hline & \multirow{2}{*}{ Item 22} & $\% 27$ Sub Group & 103 & 4.06 & 0.81 & 204 & -10.13 & .000 \\
\hline & & $\% 27$ Super Group & 103 & 4.93 & 0.32 & & & \\
\hline & \multirow{2}{*}{ Item 15} & $\% 27$ Sub Group & 103 & 3.67 & 0.94 & 204 & -7.219 & .000 \\
\hline & & $\% 27$ Super Group & 103 & 4.50 & 0.70 & & & \\
\hline \multirow{8}{*}{ 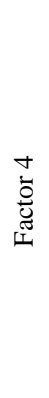 } & \multirow{2}{*}{ Item 5} & $\% 27$ Sub Group & 103 & 3.73 & 0.93 & 204 & -7.121 & .000 \\
\hline & & $\% 27$ Super Group & 103 & 4.51 & 0.62 & & & \\
\hline & \multirow{2}{*}{ Item 7} & $\% 27$ Sub Group & 103 & 3.77 & 0.99 & 204 & -8.819 & .000 \\
\hline & & $\% 27$ Super Group & 103 & 4.73 & 0.49 & & & \\
\hline & \multirow{2}{*}{ Item 6} & $\% 27$ Sub Group & 103 & 3.41 & 1.06 & 204 & -9.274 & .000 \\
\hline & & $\% 27$ Super Group & 103 & 4.55 & 0.67 & & & \\
\hline & \multirow{2}{*}{ Item 10} & $\% 27$ Sub Group & 103 & 3.45 & 1.00 & 204 & -10.471 & .000 \\
\hline & & $\% 27$ Super Group & 103 & 4.83 & 0.51 & & & \\
\hline
\end{tabular}

Table 6 demonstrates The Attitudes of The Participants Toward Child's Rights for the determination of $27 \%$ sub-super groups by ordering. We examined the lowest value of the first 103 people and the highest value of the first 103 people coinciding with $27 \%$ of the attitudes toward child's rights ordered. The $27 \%$ lower and upper 
values used in deciding on the distinctiveness of items were significant for all items $(\mathrm{p}<0.01)$. There was a significant difference between the group with

a higher attitude score and the group with a lower attitude score in the ACRS on the basis of item score and score average $(\mathrm{p}<.05)$. This indicated that the scale had a distinctiveness for the child's rights attitude to be measured and it had a higher internal consistency. In addition, since the total item correlation gave information about reliability of the scale, we calculated the total item correlation score as well. Table 7 demonstrates the correlation scores related to the scale items.

Table 7. Total 1tem correlation scores of The Attitudes of the Participants toward Child Rights

\begin{tabular}{|c|c|}
\hline Items & Item- Total Correlation Scores \\
\hline Item 18 &, 603 \\
\hline Item 21 &, 405 \\
\hline Item 33 &, 526 \\
\hline Item 30 &, 513 \\
\hline Item 38 &, 736 \\
\hline Item 32 &, 420 \\
\hline Item 28 &, 408 \\
\hline Item 14 &, 588 \\
\hline Item 29 &, 618 \\
\hline Item 27 &, 403 \\
\hline Item 12 &, 415 \\
\hline Item 19 &, 521 \\
\hline Item 13 &, 460 \\
\hline Item 22 &, 476 \\
\hline Item 5 &, 543 \\
\hline Item 7 &, 602 \\
\hline Item 6 &, 531 \\
\hline Item 10 &, 413 \\
\hline
\end{tabular}

Examining Table 7, it can be concluded that the correlation scores ranged from 0.403 to 0.618 on the basis of items. If total item correlations are .30 and above, this indicates that the item has a high rate of sampling similar behaviors and has a positive impact on increasing internal consistency of the scale. Taking these results into consideration; the Attitude toward Child's Rights Scale had a high reliability. As a consequence, we created an ultimate scale with 13 positive items, six negative items and nine factors.

\section{Discussion}

In this study we developed a scale to measure the attitudes of children toward child's rights. When the literature is examined, there are also scales prepared for children's rights. Öztürk and Doğanay [12] developed a child's rights-based school scale to monitor children's rights practices in schools. A valid and reliable measurement tool consisting of 26 items that can be used to examine environmental, administrative and social structures in schools in terms of children's rights has been created. Yurtseven Kilıçgün and Oktay [13] developed a parent attitude scale towards children's rights to examine parents' attitudes towards children's rights. The sample of the study included a total of 1486 parents, 743 mothers and 743 fathers, with children between the ages of 6-14. As a result, a five-point Likert-type scale consisting of 63 items was created. In addition, studies measuring children's attitudes about children's rights have been found [14]. However, such a study was needed considering both the age level and the general condition of the existing scales. While preparing the scale, the steps stated in the literature were followed. These stages are to create an item pool, write the scale items in a way that can measure attitudes, get expert opinion, pre-test phase, and carry out validity and reliability studies [7], ]8]. The scale study primarily began with creating an item pool in the light of items in the Convention on the Rights of the Children and the views of the children. We asked expert opinion for the items created. As a result of expert opinion and pilot applications we started validity studies for the draft scale of 30 items. In order to conduct Exploratory Factor Analysis procedures of the scale, we collected data from 384 children via Google Forms. The KMO value and the Bartlett's test results demonstrated that this number was adequate for the sample (KMO; 0,849, $\mathrm{X}^{2} ; 1.896$, df; 171 , p: .000). As a result of the Exploratory Factor Analysis, we excluded 19 items which were not included in any factor and whose item factor load was .40 and below. The remaining 19 items gathered under four factors. The totally explained variance was $51.315 \%$. We started the Confirmatory Factor Analysis procedure after collecting data from 226 children who had not completed the scale previously. The results obtained $(\chi 2 / \mathrm{sd}=2.067 \mathrm{p}<.01$; NFI $=.85$; TLI: $.90 ;$ CFI=.91; SRMR=.05; RMSEA = .07) demonstrated that fit indices of the model were good. The dimensions detected in the scale were named "Living", "Protection", "Participation" and "Development". In the reliability calculations of the scale, we found the Cronbach's Alpha reliability coefficient to be .802 Also we calculated item analysis statistics and total item correlations based on the difference of sub-super group averages within the scope of reliability analyses. There was a significant difference between the group with a higher attitude score and the group with a lower attitude score in the Attitude toward Child's Rights Scale on the basis of item score and score average. All these analyses demonstrated that the Attitude toward Child's Rights Scale of 19 items is a valid and reliable assessment tool. 


\section{Conclusions}

In the study we applied the Attitude toward Child's Rights Scale to grade three, grade four and grade five students. It is possible to test the scale also on students from other grades and conduct validity and reliability studies.

Since the study comprised students in a limited sample, we can recommend that studies with more sample be conducted.

It is also recommended that the validity and reliability English version of our attitude scale towards story writing developed in Turkish be analyzed.

\section{REFERENCES}

[1] Hart, H.L.A. "Bentham on legal rights" in A.W.B. Simpson (Ed.), Oxford Essays in Jurisprudence. Oxford: Oxford University Press, 1973.

[2] MacCormick, N. "Children's Rights: A Test-Case for Theories of Rights", Archiv für Rechts- und Sozialphilosophie, vol. 62, no.3, pp. 305-316, 1976.

[3] Brighouse, H. "What rights (if any) do children have?" in D. Archard and C. Mcleod (Eds.), in The moral and political status of children, Oxford: Oxford University Press, pp. 31-52, 2002.

[4] Brennan, S. “Children's choices or children's interests: which do their rights protect?". İn D. Archard and C. Mcleod (Eds.), The moral and political status of children.

\footnotetext{
${ }^{\mathrm{i}}$ This study was produced from the doctoral thesis prepared by Tugba Dönmez under the supervision of Prof. Dr. Selma Yel.
}

Oxford: Oxford University Press, pp. 53-69, 2002.

[5] Giesinger, J. "Children, rights, and powers. International Journal of Children's Rights", vol.27, no. 2, pp. 251-265, 2019. DOI: $10.1163 / 15718182-02702003$

[6] Creswell, J. W. "Research design: Qualitative, quantitative, and mixed methods approaches" (2nd ed.). Thousand Oaks: Sage Publications, 2003.

[7] Büyüköztürk, Ş. "Sosyal bilimler için veri analizi el kitabı" (27. bask1). Ankara: Pegem Yayıncılık, 2020.

[8] Tavşancıl, E. "Tutumların ölçülmesi ve SPSS ile veri analizi," Nobel Yayıncılık: Ankara, 2002.

[9] Tabachnick, B. G. \& Fidell, L. S. "Using multivariate statistics," Boston: Pearson, 2003.

[10] Cohen, L., Manion, L., \& Morrison, K.. "Research methods in education," New York: Routledge, 2002.

[11] Hu, L. T. ve Bentler, P. M. "Cutoff criteria for fit indexes in covariance structure analysis: conventional criteria versus new alternatives," Structural Equation Modeling: A Multidisciplinary Journal, vol.6, no. 1, pp. 1-55, 2009. DOI: 10.1080/10705519909540118

[12] Kilıçgün, Müge Yurtsever. "Çocuk Haklarına Yönelik Ebeveyn Tutum Ölçeği'nin Geliştirilmesi ve Standardizasyonu." Dokuz Eylül Üniversitesi Buca Eğitim Fakültesi Dergisi vol. 31, pp.1-22, 2011

[13] Öztürk, A., \& Doğanay, A.” Çocuk Hakları Temelli Okul Ölçeğinin Geliştirilmesi”, Trakya Üniversitesi Sosyal Bilimler Dergisi, vol. 19, no. 1, pp. 41-58, 2017.

[14] Topçu, B. "Yaratıı Drama Temelli Çocuk Hakları Eğitimi Programının Geliştirilmesi ve Uygulanması", Yüksek Lisans Tezi, Gaziantep Üniversitesi Eğitim Bilimleri Enstitüsü, Gaziantep, 2019. 